\title{
GlbN (Cyanoglobin) Is a Peripheral Membrane Protein That Is Restricted to Certain Nostoc spp.
}

\author{
DONNA R. HILL, ${ }^{1}$ THOMAS J. BELBIN, ${ }^{2}$ MARC V. THORSTEINSSON, ${ }^{1}$ DEENI BASSAM, ${ }^{1}$ \\ SUSANNE BRASS, ${ }^{3}$ ANNELIESE ERNST, ${ }^{3}$ PETER BÖGER, ${ }^{3}$ HANS PAERL, ${ }^{4}$ \\ MARTIN E. MULLIGAN, ${ }^{2 *}$ AND MALCOLM POTTS ${ }^{1 *}$ \\ Department of Biochemistry and Anaerobic Microbiology, Virginia Polytechnic Institute and State University, \\ Blacksburg, Virginia 24061 ${ }^{1}$; Department of Biochemistry, Memorial University of Newfoundland,

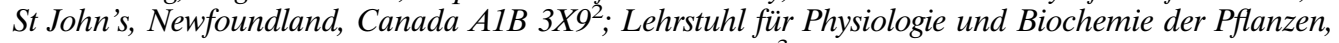 \\ Universität Konstanz, D-78434 Konstanz, Germany ; and Institute of Marine Sciences, \\ University of North Carolina at Chapel Hill, Morehead City, North Carolina 28557
}

Received 9 May 1996/Accepted 29 August 1996

\begin{abstract}
The glbN gene of Nostoc commune UTEX 584 is juxtaposed to nifU and nifH, and it encodes a 12-kDa monomeric hemoglobin that binds oxygen with high affinity. In $N$. commune UTEX 584, maximum accumulation of GlbN occurred in both the heterocysts and vegetative cells of nitrogen-fixing cultures when the rate of oxygen evolution was repressed to less than $25 \mu \mathrm{mol}$ of $\mathrm{O}_{2} \mathrm{mg}$ of chlorophyll $a^{-1} \mathrm{~h}^{-1}$. Accumulation of GlbN coincided with maximum synthesis of $\mathrm{NifH}$ and ferredoxin $\mathrm{NADP}^{+}$oxidoreductase (PetH or FNR). A total of 41 strains of cyanobacteria, including 40 nitrogen fixers and representing 16 genera within all five sections of the cyanobacteria were screened for the presence of $g l b N$ or GlbN. $g l b N$ was present in five Nostoc strains in a single copy. Genomic DNAs from 11 other Nostoc and Anabaena strains, including Anabaena sp. strain PCC 7120, provided no hybridization signals with a $g l b N$ probe. A constitutively expressed, 18-kDa protein which cross-reacted strongly with GIbN antibodies was detected in four Anabaena and Nostoc strains and in Trichodesmium thiebautii. The nifU-nifH intergenic region of Nostoc sp. strain MUN 8820 was sequenced $(1,229$ bp) and was approximately $95 \%$ identical to the equivalent region in $N$. commune UTEX 584. Each strand of the DNA from the nifU-nifH intergenic regions of both strains has the potential to fold into secondary structures in which more than $50 \%$ of the bases are internally paired. Mobility shift assays confirmed that NtcA (BifA) bound a site in the nifU-glbN intergenic region of $N$. commune UTEX 584 approximately 100 bases upstream from the translation initiation site of $g l b N$. This site showed extensive sequence similarity with the promoter region of $g \ln A$ from Synechococcus sp. strain PCC 7942. In vivo, GlbN had a specific and prominent subcellular location around the periphery of the cytosolic face of the cell membrane, and the protein was found solely in the soluble fraction of cell extracts. Our hypothesis is that GlbN scavenges oxygen for and is a component of a membrane-associated microaerobically induced terminal cytochrome oxidase.
\end{abstract}

Gene expression in prokaryotic cells is influenced markedly by $\mathrm{pO}_{2}$. Bacteria may use proteins which bind oxygen or which respond to changes in redox potential in order to coordinate their physiological responses during growth under oxic or anoxic conditions. Examples of bacterial heme proteins that can reversibly bind molecular oxygen include VHb in Vitreoscilla sp. (28), Hmp in Escherichia coli (56), FixL in Rhizobium meliloti (15), and GlbN (cyanoglobin) in the cyanobacterium Nostoc commune UTEX 584 (42). GlbN is a monomeric hemoglobin that binds oxygen reversibly, with high affinity, and with noncooperativity (54). The gene that encodes cyanoglobin, $g l b N$, is positioned between nifU and nifH. These two nif genes are components of two contiguous operons in most cyanobacteria that have been characterized to date, and their products are essential for nitrogen fixation. However, the function of cyanoglobin in nitrogen fixation remains cryptic.

Some filamentous cyanobacteria, including Nostoc species, have the capacity to differentiate heterocysts when they are deprived of a source of fixed nitrogen. The structural and biochemical modifications of heterocysts contribute to the de-

\footnotetext{
* Corresponding author. For M. Potts, information is as follows: Phone: (540) 231-5745. Fax: (540) 231-9070. Electronic mail address: geordie@vt.edu. For M. E. Mulligan, information is as follows: Phone: (709) 737-7978. Fax: (709) 737-2422. Electronic mail address: mulligan @morgan.ucs.mun.ca.
}

velopment of a cellular environment that is conducive to the sustained activity of nitrogenase under oxic growth conditions $(19,59)$. In a cell-free system, nitrogenase is rapidly inactivated in air. Certain of the modifications that arise during the differentiation of the cyanobacterial heterocyst may alleviate the effects of potentially toxic oxygen concentrations. These modifications include the loss of photosystem II function (19), the formation of a diffusion barrier with a reduced permeability to gases including oxygen $(29,40)$, attenuation of oxygen tension through the coupling of diffusion-limited kinetics and respiratory electron transport (39), and modification of nitrogenase to an $\mathrm{O}_{2}$-insensitive form (51). The maturation of heterocysts can be blocked when mutations are introduced in genes that contribute to the developmental pathway $(5,58)$. One of these genes, $n t c A$, encodes a transcription factor that is known to positively regulate genes, such as nir $A$ and $g \ln A$, whose expression is negatively regulated by ammonia (31).

A range of non-heterocyst-forming cyanobacteria including unicellular and filamentous forms also have the capacity for nitrogen fixation. These cyanobacteria employ a number of different, incompletely understood, strategies to protect their nitrogenases from inactivation by oxygen (11). Recently, evidence was found for a second functional Nif system, Nif2, which operates in the vegetative cells of Anabaena variabilis ATCC 29413 exclusively under anoxic conditions after the cells have been starved of combined nitrogen $(50,53)$. These find- 
ings underscore the diversity and complexity of nitrogenase synthesis and nif regulation in cyanobacteria.

To understand the function of cyanoglobin, we studied the factors that control the synthesis of this protein, determined its distribution in heterocyst-forming and non-heterocyst-forming (nitrogen-fixing) cyanobacteria, and investigated its cellular and subcellular location in N. commune UTEX 584.

\section{MATERIALS AND METHODS}

Cyanobacterial strains. Cyanobacteria were cultured in BG-11 or BG-11 medium (46), Allen and Arnon medium (1), or Chu-10 (7) medium as described in the text and figure legends. Descriptions of the conditions of growth for $N$. commune UTEX 584 were provided elsewhere (43). Colonies of a strain of the marine cyanobacterium Trichodesmium thiebautii were collected in Atlantic waters $5 \mathrm{~km}$ South of Beaufort Inlet, N.C. The cells were fixing atmospheric nitrogen actively at the time of their collection (44).

Taxonomy. The cyanobacterial strains used are listed in Table 1. The strains are grouped according to the classification scheme of Rippka et al. (46). Further details of some of the strains used in this study are found in references 45 and 46 , while reference 13 provides further information on more classical aspects of cyanobacterial taxonomy. The attributes that provide a means to discriminate unambiguously between a Nostoc or Anabaena form are unclear. For this reason, we simply retained the designations that were provided with the strains as we received them for study. For example, we retained the use of the epithet Anabaena sp. strain PCC 7120 but are aware that the alternative designation Nostoc sp. strain PCC 7120 has been proposed (45).

Growth of cyanobacteria. $N$. commune UTEX 584 and DRH1 and Anabaena sp. strain PCC 7120 were grown in $250 \mathrm{ml}$ of liquid medium in 1-liter capacity (internal diameter, $5 \mathrm{~cm}$ ) airlift fermentors at $32^{\circ} \mathrm{C}$. Cultures were sparged continuously with sterile filtered $5 \%$ (vol/vol) $\mathrm{CO}_{2}$ in air (oxic conditions) or with $5 \%$ (vol $/ \mathrm{vol}$ ) $\mathrm{CO}_{2}$ in argon (microoxic conditions). With the use of the latter gas mixture, the growth medium was supplemented with $20 \times$ the concentration of $\mathrm{Na}_{2} \mathrm{CO}_{3}$ specified for $\mathrm{BG}-11_{\mathrm{O}}$ medium. Irradiation was provided by banks of fluorescent 15-Watt strip lights (Sylvania). At the time of inoculation of media, the incident photon flux density was approximately $50 \mu \mathrm{mol}$ of photons $\mathrm{m}^{-2} \mathrm{~s}^{-1}$ at the surface of the fermentors. As cultures became denser, the photon flux density was increased, in steps, such that at the termination of experiments the incident photon flux density was approximately $300 \mu \mathrm{mol}$ of photons $\mathrm{m}^{-2} \mathrm{~s}^{-1}$. Cultures of other strains were grown under similar conditions (see figure legends)

Induction of GlbN synthesis. Two methods were used to induce GlbN synthesis, and details are provided in the figure legends.

Nitrogenase activity and oxygen evolution. The growth stage of cells was monitored periodically during growth through light microscopy. Acetylene was generated with calcium carbide, and nitrogenase activity was measured by the acetylene reduction assay technique as described elsewhere (52). Respiratory oxygen uptake was not measured and was not considered upon calculation of the rates of oxygen evolution. The rates of ethylene generation and oxygen evolution were calculated by using purified standards of ethylene and oxygen, respectively. The rates were calculated on the basis of values of total protein, chlorophyll $a$ content, and dry weight, which were determined by methods described elsewhere (48).

Isolation and purification of proteins. Protein extracts were obtained either by grinding cells under liquid nitrogen in the presence of Laemmli buffer (30) that had been modified through the addition of protease inhibitors (21) or by passing cells at least twice through a French pressure cell at $110 \mathrm{MPa}$. Purification of proteins through fast-protein liquid chromatography and subsequent analysis of native or denatured proteins followed published protocols $(21,42)$.

Cell fractionation. Cell wall and cytoplasmic membrane fractions were obtained from $N$. commune UTEX 584 (cell pellets, $50 \mathrm{~g}$ [wet weight]) by the method described by Olie and Potts (41). Purified heterocyst preparations were obtained from $A$. variabilis ATCC 29413 as described by Häfele et al. (17).

Purification of antisera. $g l b N$ was expressed in E. coli BL21 DE3(pGlbN) (42), and purified recombinant GlbN was used to raise polyclonal antibodies in rabbits. Three different procedures were used to purify the antiserum. In the first procedure, $1 \mathrm{ml}$ of the antiserum was incubated at room temperature in a $35 \times$ $10-\mathrm{mm}$ petri dish (Falcon) with $2-\mathrm{cm}^{2}$ nitrocellulose sheets that had been allowed to adsorb a cell lysate of $E$. coli BL21 DE3 (23). This antiserum is referred to as antiserum A and was used in Western analyses (see below). For immunocytochemical analyses, antiserum A was purified further by a modified form of the technique described by Gruber and Zingales (16). Antiserum A was diluted 1:50 in a mixture of $10 \mathrm{mM}$ Tris- $\mathrm{HCl}(\mathrm{pH} 7.5)-100 \mathrm{mM} \mathrm{NaCl}-1 \mathrm{mM}$ EDTA (TBS) and $1 \%(\mathrm{wt} / \mathrm{vol})$ bovine serum albumin and was then incubated with autoclaveand formalin-treated bacterial cells. One batch of antiserum A was treated with cell preparations from E. coli BL21 DE3(pTrc99A) only; this is referred to as antiserum B. A second batch of antiserum A was treated with cell preparations from both E. coli BL21 DE3(pTrc99A) and Anabaena sp. strain PCC 7120; this is referred to as antiserum $\mathrm{C}$.

Western analyses. For analytical purposes, proteins were resolved under de- naturing conditions in the presence of sodium dodecyl sulfate (SDS) in 0.75 mm-thick $15 \%$ (wt/vol) polyacrylamide gels with the use of a Mighty Small II SE 250 gel apparatus (Hoefer). Proteins were visualized using either Coomassie blue or silver staining (35). Western blotting (immunoblotting) was performed with either of two published protocols $(34,49)$. The concentrations of primary antibodies are given in the figure legends. The secondary antibodies were goat anti-rabbit immunoglobulin G-horseradish peroxidase conjugate (affinity purified; Bio-Rad) used at a dilution of between 1:1,000 and 1:3,000 for up to $4 \mathrm{~h}$ at room temperature.

Southern analysis. Genomic DNA was obtained from the different cyanobacteria following the procedure described by Jackman and Mulligan (24) or that described by Xie and Potts (60). The conditions for transfer to Hybond (Amersham) or Gene Screen (NEN Research Products), preparation of digoxigeninlabelled or radioactively labelled probes, hybridization, washing, and probe detection were as described elsewhere $(24,60)$

Cloning, nucleotide sequencing, and analysis. Restriction enzymes, other enzymes, and materials used in molecular cloning (obtained variously from New England Biolabs, Life Technologies, Boehringer Mannheim, Pharmacia, Promega, Stratagene, and U.S. Biochemicals), DNA manipulations, and analyses were performed according to standard procedures $(4,47)$. Analysis of nucleotide sequences was carried out with DNAlysis (W. Buikema, University of Chicago), MulFold, and LoopDLoop (14, 25, 26, 61).

Gel retardation assays. Plasmid pNDH1 (Table 1) (9) was digested with AluI, and a 781-bp fragment, corresponding to bases 262 to 1042 described by Angeloni and Potts (2), was isolated and subcloned in pGEM-4 as pMVT1. The 781-bp fragment was then digested with $D p n I$ to generate a 445-bp fragmen corresponding to bases 598 to 1042 (subcloned in pGEM-4 as pMVT2). Five picomoles (approximately $0.7 \mu \mathrm{g}$ ) of the 445 -bp fragment was incubated with 25 $\mu \mathrm{Ci}$ of $\left.\left[\gamma^{-32} \mathrm{P}\right] \mathrm{dATP} \mu\right]^{-1}$ in the presence of $10 \mathrm{U}$ of T4 polynucleotide kinase in a reaction volume of $25 \mu \mathrm{l}$. Gel retardation assays were completed with the end-labelled 445-bp fragment (see Fig. 5A) and NtcA-enriched lysates according to the protocols described by Luque et al. (31) and Ausubel et al. (4).

Electron microscopy. General techniques for the embedding, fixing, and sectioning of cyanobacterial cells for electron microscopy and or immunocytochemical analysis were as described elsewhere $(21,22)$; further details are provided in figure legends.

Nucleotide sequences. The nucleotide sequence of a 1,229-bp region of Nostoc sp. strain 8820 containing $g l b N$ and the partial coding regions of nif $U$ and nifH was deposited in the GenBank Nucleic Acid Database under accession number L47979. A 3,525-bp sequence containing the nifU-glbN-nifD-nifH region of $N$. commune UTEX 584 has been deposited under accession number L23514 (locus NOSMOFENIF [2]).

\section{RESULTS}

Synthesis of GlbN, NifH, and PetH by $N$. commune UTEX 584. We first studied the synthesis of GlbN, together with that of dinitrogenase reductase $(\mathrm{NifH})$ and ferredoxin $\mathrm{NADP}^{+}$oxidoreductase (PetH or FNR), under oxic and microoxic conditions. NifH synthesis provides a marker for nif expression. PetH transfers electrons from NADPH to FdxH, the immediate electron donor to $\mathrm{NifH}$ (nitrogenase) in heterocysts (see reference 18).

When $N$. commune UTEX 584 was grown with $5 \%$ (vol $/ \mathrm{vol}$ ) $\mathrm{CO}_{2}$ in air, either in continuous light or under a light-dark (12 $\mathrm{h}: 12 \mathrm{~h}$ ) cycle for periods of up to $276 \mathrm{~h}$ in $\mathrm{BG}-11_{\mathrm{O}}$, neither GlbN, NifH, nor PetH was detectable (FNR [Fig. 1]). Lysates from cells that were incubated for $60 \mathrm{~h}$ following microoxic stepdown provided visually conspicuous cross-reactions with NifH antibodies upon immunoblotting (Fig. 1). The increase in the amount of NifH in cells was accompanied by an increase in the capacity of the cells to reduce acetylene with rates of ethylene generation between 6.0 and $10.9 \mathrm{nmol}$ of ethylene evolved $\mu \mathrm{g}$ of chlorophyll $a^{-1} \mathrm{~min}^{-1}$. GlbN was detectablethe reaction on the blots was weak and sometimes only just discernible to the eye-within approximately $24 \mathrm{~h}$ after the imposition of microoxic conditions. However, only extracts from cells that had been incubated under microoxic conditions for at least $108 \mathrm{~h}$ provided strong cross-reactions with $\mathrm{GlbN}$ - or PetH-specific antibodies (Fig. 1). These extracts contained the greatest amounts of NifH and contained additional polypeptides that cross-reacted with NifH. Further experiments confirmed that the latter polypeptides arose through degradation 
TABLE 1. Strains and plasmids used ${ }^{a}$

\begin{tabular}{|c|c|c|c|c|c|}
\hline Strain or plasmid & Description & $g l b N$ & GlbN & $\begin{array}{l}18-\mathrm{kDa} \\
\text { protein }\end{array}$ & Source or reference \\
\hline \multicolumn{6}{|l|}{ Section I } \\
\hline Synechococcus sp. strain PCC 7942 & Coccoid, nonheterocystous, does not fix $\mathrm{N}_{2}$ & & $--^{b}$ & - & UK \\
\hline Synechocystis sp. strain BO 8402 & $\begin{array}{l}\text { Isolated from the Bodensee by A. Ernst; } \\
\text { coccoid, nonheterocystous, microaerobic } \mathrm{N}_{2} \\
\text { fixation }\end{array}$ & & - & - & UK \\
\hline \multicolumn{6}{|c|}{ 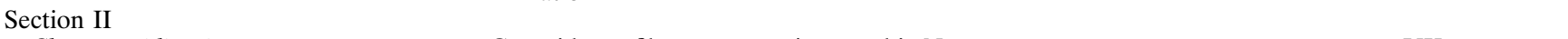 } \\
\hline Chroococcidiopsis sp. & $\begin{array}{l}\text { Coccoid, nonfilamentous, microaerobic } \mathrm{N}_{2} \\
\text { fixation; isolated by S. Scherer }\end{array}$ & & - & - & UK \\
\hline \multicolumn{6}{|c|}{ - } \\
\hline Oscillatoria sp. strain PCC 7515 & $\begin{array}{l}\text { Filamentous, nonheterocystous, microaerobic; } \\
\text { facultative photoheterotroph }\end{array}$ & - & & & PCC \\
\hline Phormidium foveolarum B1462-1 & $\begin{array}{l}\text { Filamentous, nonheterocystous, microaerobic } \mathrm{N}_{2} \\
\quad \text { fixation; probably equivalent to strain B1442-1 }\end{array}$ & & - & - & UK \\
\hline Phormidium foveolarum B1442-1 & $\begin{array}{l}\text { Filamentous, nonheterocystous, microaerobic } \mathrm{N}_{2} \\
\text { fixation }\end{array}$ & - & & & R. Haselkorn \\
\hline Pseudanabaena sp. strain PCC 7403 & $\begin{array}{l}\text { Filamentous, nonheterocystous, microaerobic } \mathrm{N}_{2} \\
\text { fixation }\end{array}$ & - & & & PCC \\
\hline Trichodesmium sp. & $\begin{array}{l}\text { Filamentous, nonheterocystous, aerobic } \mathrm{N}_{2} \\
\text { fixation; collected in Atlantic, } 5 \mathrm{~km} \text { south of } \\
\text { Beaufort Inlet, N.C. }\end{array}$ & & - & $+^{c}$ & H. Paerl \\
\hline \multicolumn{6}{|c|}{ 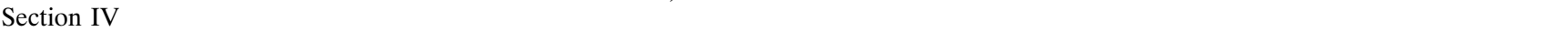 } \\
\hline Anabaena sp. strain PCC 7120 & $\begin{array}{l}\text { Filamentous, heterocysts, aerobic } \mathrm{N}_{2} \text { fixation; } \\
\quad=\text { ATCC } 27347+\text { ATCC } 27893\end{array}$ & - & - & $+^{c}$ & J. Elhai \\
\hline Anabaena sp. strain PCC 7120 & $\begin{array}{l}\text { Filamentous, heterocysts, aerobic } \mathrm{N}_{2} \text { fixation; } \\
\quad=\text { ATCC } 27347=\text { ATCC } 27893\end{array}$ & - & & & R. Haselkorn \\
\hline Anabaena sp. strain PCC 7118 & $\begin{array}{l}\text { Filamentous, Het }{ }^{-} \mathrm{Nif}^{+} \text {(microaerobic) } \\
\quad=\text { Nostoc muscorum }=\text { ATCC } 27892\end{array}$ & & - & $+^{c}$ & ATCC \\
\hline Anabaena sp. strain PCC 7119 & $\begin{array}{l}\text { Filamentous, heterocysts, aerobic } \mathrm{N}_{2} \text { fixation; } \\
\quad=\text { Nostoc } \mathrm{sp} .=\text { ATCC } 29151\end{array}$ & & - & $+^{c}$ & ATCC \\
\hline Anabaena variabilis ATCC 29413 & $\begin{array}{l}\text { Filamentous, heterocysts, aerobic } \mathrm{N}_{2} \text { fixation; } \\
\quad=\text { PCC } 7937\end{array}$ & - & - & $+^{c}$ & UK \\
\hline Anabaena sp. strain $\mathrm{CH} 1$ & Filamentous, heterocysts, aerobic $\mathrm{N}_{2}$ fixation & & - & - & UK \\
\hline Anabaena sp. strain CA & $\begin{array}{l}\text { Filamentous, heterocysts, aerobic } \mathrm{N}_{2} \text { fixation; } \\
=\text { ATCC } 33047\end{array}$ & - & & & R. Haselkorn \\
\hline Anabaena sp. strain L31 & $\begin{array}{l}\text { Filamentous, heterocysts, aerobic } \mathrm{N}_{2} \text { fixation; } \\
\text { from S. Apte-J. Thomas }\end{array}$ & - & & & R. Haselkorn \\
\hline Anabaena sp. strain PCC 77S15 & $\begin{array}{l}\text { Filamentous, heterocysts, aerobic } \mathrm{N}_{2} \text { fixation; } \\
\text { from C. Franche }\end{array}$ & $+^{d}$ & & & R. Haselkorn \\
\hline Anabaena torulosa & $\begin{array}{l}\text { Filamentous, heterocysts, aerobic } \mathrm{N}_{2} \text { fixation; } \\
\text { from S. Apte-J. Thomas }\end{array}$ & - & & & R. Haselkorn \\
\hline Anabaena azollae $1 \mathrm{a}$ & Filamentous, heterocysts, aerobic $\mathrm{N}_{2}$ fixation & - & & & R. Haselkorn \\
\hline Nodularia sp. strain PCC 73104 & $\begin{array}{l}\text { Filamentous, heterocysts, aerobic } \mathrm{N}_{2} \text { fixation; } \\
\text { (slow growth); facultative heterotroph }\end{array}$ & $+^{d}$ & & & PCC \\
\hline Cylindrospermum sp. strain PCC 7604 & Filamentous, heterocysts, aerobic $\mathrm{N}_{2}$ fixation & $+{ }^{d}$ & & & PCC \\
\hline Nostoc commune UTEX 584 & Filamentous, heterocysts, aerobic $\mathrm{N}_{2}$ fixation & + & + & $+^{c}$ & VPI \\
\hline Nostoc sp. strain MUN 8820 & $\begin{array}{l}\text { Filamentous, heterocysts, aerobic } \mathrm{N}_{2} \text { fixation; } \\
\text { isolated as minor contaminant from culture of } \\
\text { Oscillatoria tenuis SAUG 1459-1 }\end{array}$ & + & & & H. Böhme \\
\hline Nostoc sp. strain 840215 & $\begin{array}{l}\text { Filamentous, heterocysts, aerobic } \mathrm{N}_{2} \text { fixation; } \\
\text { origin unknown }\end{array}$ & + & & & R. Haselkorn \\
\hline Nostoc sp. strain UCD 7801 & Filamentous, heterocysts, aerobic $\mathrm{N}_{2}$ fixation & + & & & J. Meeks \\
\hline Nostoc sp. strain MACR2 & $\begin{array}{l}\text { Filamentous, heterocysts, aerobic } \mathrm{N}_{2} \text { fixation; } \\
\text { isolated by } \mathrm{J} \text {. Meeks }\end{array}$ & $+^{d}$ & & & R. Haselkorn \\
\hline N. commune DRH1 & $\begin{array}{l}\text { Filamentous, heterocysts, aerobic } \mathrm{N}_{2} \text { fixation; } \\
\text { isolated by Donna Hill }\end{array}$ & & - & $+^{c}$ & VPI \\
\hline Nostoc sp. strain ATCC 27896 & $\begin{array}{l}\text { Filamentous, heterocysts, aerobic } \mathrm{N}_{2} \text { fixation; } \\
\quad=\text { PCC } 6310\end{array}$ & & - & - & C. P. Wolk \\
\hline Nostoc sp. strain ATCC 27897 & Filamentous, heterocysts, aerobic $\mathrm{N}_{2}$ fixation & + & & & R. Haselkorn \\
\hline Nostoc sp. strain ATCC 29107 & Filamentous, heterocysts, aerobic $\mathrm{N}_{2}$ fixation & - & & & R. Haselkorn \\
\hline Nostoc sp. strain ATCC 29133 & $\begin{array}{l}\text { Filamentous, heterocysts, aerobic } \mathrm{N}_{2} \text { fixation; } \\
\quad=\text { PCC } 73102\end{array}$ & & - & - & C. P. Wolk \\
\hline Nostoc sp. strain 268 & $\begin{array}{l}\text { Filamentous, heterocysts, aerobic } \mathrm{N}_{2} \text { fixation; } \\
\text { facultative heterotroph (on fructose); isolated } \\
\text { by T. Vaara from the Baltic Sea }\end{array}$ & & $+^{e}$ & & K. Jäger \\
\hline Nostoc gunnera 8001 & $\begin{array}{l}\text { Filamentous, heterocysts, aerobic } \mathrm{N}_{2} \text { fixation; } \\
\text { cyanobiont of Gunnera albocarpa, isolated by } \\
\text { J. Horstmann; collection of J. Meeks }\end{array}$ & & $-^{e}$ & & K. Jäger \\
\hline
\end{tabular}


TABLE $1-$ Continued

\begin{tabular}{|c|c|c|c|c|c|}
\hline Strain or plasmid & Description & $g l b N$ & GlbN & $\begin{array}{l}18-\mathrm{kDa} \\
\text { protein }\end{array}$ & Source or reference \\
\hline Nostoc commune SAUG 1453-3 & $\begin{array}{l}\text { Filamentous, heterocysts, aerobic } \mathrm{N}_{2} \text { fixation; } \\
\text { may be same strain as } N \text {. commune UTEX } \\
584 \text {; low frequency of heterocysts }\end{array}$ & & $+^{e}$ & & K. Jäger \\
\hline Nostoc sp. strain PCC 9229 & Filamentous, heterocysts, aerobic $\mathrm{N}_{2}$ fixation & & $+^{e}$ & & K. Jäger \\
\hline Scytonema sp. strain PCC 7110 & $\begin{array}{l}\text { Filamentous, heterocysts, aerobic } \mathrm{N}_{2} \text { fixation; } \\
\text { distinct aerial growth; facultative heterotroph }\end{array}$ & $+^{d}$ & & & PCC \\
\hline Tolypothrix sp. strain SAUG 1410-1 & $\begin{array}{l}\text { Filamentous, heterocysts, aerobic } \mathrm{N}_{2} \text { fixation; } \\
\text { assignment questionable-received as } \\
\text { Calothrix membranaceae from H. Böhme and } \\
\text { subsequently classified as a Tolypothrix strain } \\
\text { (45a) }\end{array}$ & $+^{d}$ & & & R. Haselkorn \\
\hline $\begin{array}{l}\text { Calothrix sp. strain PCC } 7102 \\
\text { Section V }\end{array}$ & Filamentous, heterocysts, aerobic $\mathrm{N}_{2}$ fixation & - & & & PCC \\
\hline Fischerella sp. strain PCC 7414 & Filamentous, heterocysts, aerobic $\mathrm{N}_{2}$ fixation & - & & & PCC \\
\hline Fischerella sp. strain SAUG $1447-1$ & $\begin{array}{l}\text { Filamentous, heterocysts, aerobic } \mathrm{N}_{2} \text { fixation; } \\
\text { may be equivalent to PCC } 7414\end{array}$ & & - & - & UK \\
\hline Chlorogloeopsis sp. strain PCC 6912 & $\begin{array}{l}\text { Filamentous, heterocysts, aerobic } \mathrm{N}_{2} \text { fixation; } \\
\text { facultative heterotroph }\end{array}$ & - & & & PCC \\
\hline \multicolumn{6}{|l|}{ Recombinant plasmids } \\
\hline pNDH1 & $\begin{array}{l}\text { 2.4-kb EcoRI-HindIII fragment cloned in } \\
\text { pBR322, containing nifU-glbN-nifH of } N \text {. } \\
\text { commune UTEX } 584 \text { (GenBank accession } \\
\text { number L23514) }\end{array}$ & & & & 9 \\
\hline pMVT1 & $\begin{array}{l}\text { 781-bp AluI fragment from pNDH1 cloned in } \\
\text { pGEM-4 }\end{array}$ & & & & This study \\
\hline pMVT2 & $\begin{array}{l}\text { 445-bp } D p n \mathrm{I}-A l u \mathrm{I} \text { fragment from pMVT1 cloned } \\
\text { in pGEM-4 (putative promoter region of } \\
g l b N)\end{array}$ & & & & This study \\
\hline pCS126 & $\begin{array}{l}\text { 964-bp } M s c \mathrm{I}-P v u \mathrm{II} \text { fragment containing a } \\
\text { truncated form of Synechococcus } \text { sp. strain } \\
\text { PCC } 7942(\text { ntc } A) \text { in pTrc99A; obtained from } \\
\text { A. Herrero }\end{array}$ & & & & 31 \\
\hline pTrc99A & $\begin{array}{l}\text { 4.2-kb; } \mathrm{Amp}^{\mathrm{r}} \text { lacl }^{\mathrm{q}} \mathrm{P}_{\text {trc }} r r n B T 1 T 2 ; \text { obtained from } \\
\text { Pharmacia Biotech, Piscataway, N.J. }\end{array}$ & & & & \\
\hline
\end{tabular}

${ }^{a}$ The classification scheme for strains proposed by Rippka et al. (46) was used. MUN, Memorial University of Newfoundland; UK, Universität Konstanz; PCC, Pasteur Culture Collection; VPI, Virginia Tech; ATCC, American Type Culture Collection.

${ }^{b}-$, no immunorelated protein detected.

$c+$, immunorelated protein of $18 \mathrm{kDa}$ detected.

${ }^{d}$ Weak hybridization under moderate stringency.

${ }^{e}$ Cells of Nostoc sp. strain 268, Nostoc gunnera 8001, Nostoc commune SAUG 1453-3, and Nostoc sp. strain PCC 9229 were grown in BG-11 ${ }_{\mathrm{O}}$ in airlift fermentors similar to those used in the present study, with GlbN induction by using sparging with argon. GlbN was detected through Western blotting with GlbN antiserum A used at a dilution of 1:7,000 (26a).

of NifH by an activity that was insensitive to the proteolytic inhibitors present in extraction buffers (data not shown).

GlbN and glbN homologs in Anabaena and Nostoc spp. No protein with a size equivalent to that of $N$. commune UTEX $584 \mathrm{GlbN}$ was made by any cyanobacterial strain when tested under a wide range of growth conditions. When grown under conditions that induced synthesis of GlbN in $N$. commune UTEX 584, cell extracts from Anabaena sp. strains PCC 7120, PCC 7118, and ATCC 29413 and N. commune DRH1 each provided a specific, conspicuous cross-reaction with GlbN antiserum A (Fig. 2A and B). Extracts from cells of Nostoc strains ATCC 27896 and ATCC 29133, grown under the same conditions, provided no such cross-reaction (Fig. 2B). In each case in which a reaction was noted, it corresponded to a single polypeptide of $18 \mathrm{kDa}$ (Fig. 2A and B). Careful inspection of Western blots suggested that the cross-reacting $18-\mathrm{kDa}$ protein may be a doublet (e.g., Fig. 2A, lanes b, d, e, and i; Fig. 2C, lanes $a, b$, and c), but attempts to improve the resolution of the two bands were unsuccessful. In experiments that used different detergents and chaotropic agents, which were designed to extract and resolve proteins under different buffer conditions, no evidence was obtained to suggest that the reaction at 18 $\mathrm{kDa}$ reflected the association of a smaller protein with other proteins and/or membrane complexes.

Further studies of the synthesis of the 18-kDa protein in $A$. variabilis ATCC 29413 and Anabaena sp. strain 7119 (Nostoc muscorum) indicated that synthesis of this protein was constitutive, i.e., synthesis was not influenced either by $\mathrm{pO}_{2}, \mathrm{~N}$ source, or light or dark conditions in both strains (Fig. 2C). However, some variation was noted in the relative abundance of the $18-\mathrm{kDa}$ protein in different experiments. For example, cultures of $N$. commune UTEX 584 grown in fermentors with controlled gassing contained no detectable protein of this size (Fig. 1). However, small-scale cultures, subjected to intermittent gassing, sometimes did (Fig. 2A, lane b). Experiments to characterize the amino acid sequence of the $18-\mathrm{kDa}$ protein purified from Anabaena sp. strain PCC 7120 were unsuccessful because the $\mathrm{N}$ terminus was found to be blocked.

No cross-reactive proteins were detected in a broad range of heterocyst-forming and non-heterocyst-forming strains, including Fischerella sp. strain SAUG 1447-1, Anabaena sp. strain CHI, Phormidium foveolarum B1462-1, Synechococcus sp. 


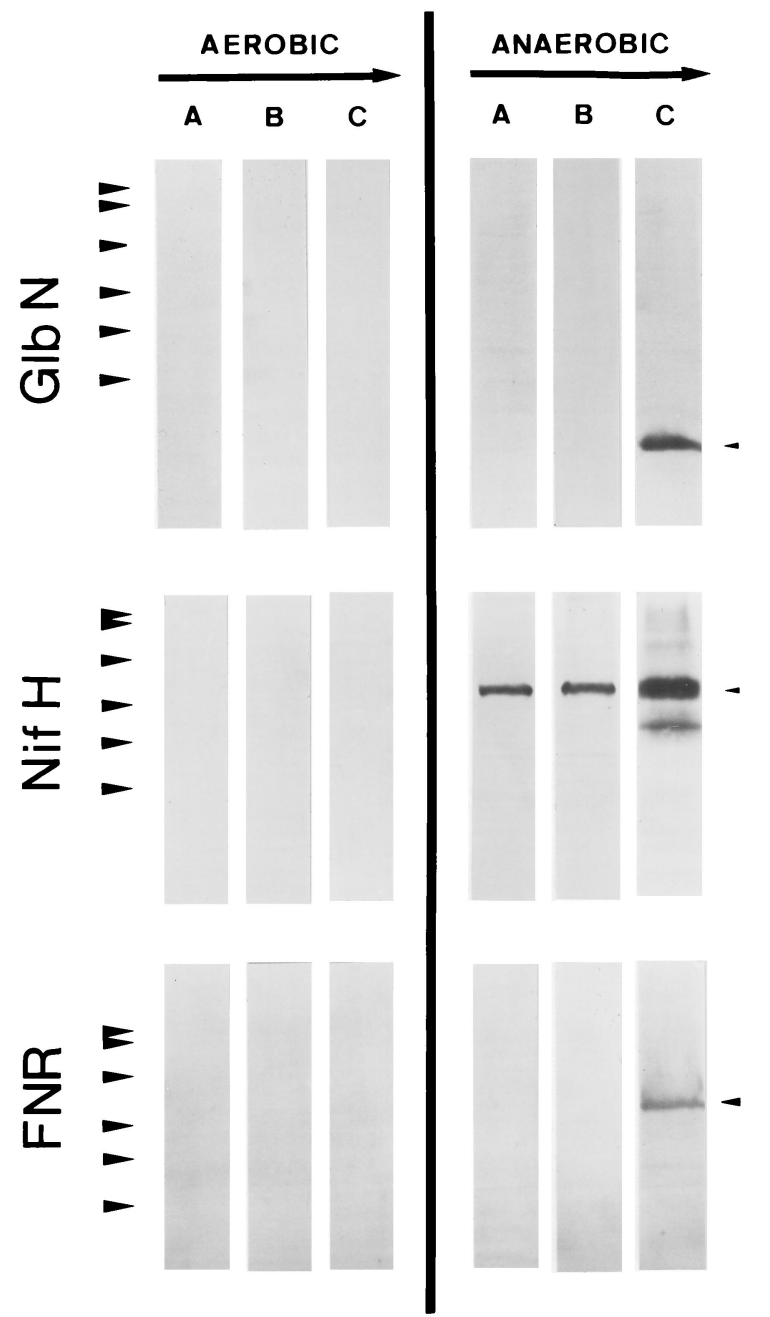

FIG. 1. GlbN, NifH, and PetH (FNR) accumulate in N. commune UTEX 584 cells following microoxic stepdown. Cultures of $N$. commune UTEX 584 were grown in fermentors at $32^{\circ} \mathrm{C}$ in BG-11 $\mathrm{O}$. Two cultures were initially grown under oxic conditions; one was subjected to microoxic stepdown $\left(5 \%[\mathrm{vol} / \mathrm{vol}] \mathrm{CO}_{2}\right.$ in argon) after $168 \mathrm{~h}$, while the other was maintained under oxic gas conditions. In this experiment, cultures were grown with a light-dark cycle (12 h:12 h). Cell lysates were prepared from both cultures 60 (lanes A), 84 (lanes B), or 108 (lanes C) $\mathrm{h}$ following the time at which one culture was subjected to microoxic stepdown. Approximately $10 \mu \mathrm{g}$ of each extract was resolved in a 15\% (wt/vol) SDS-PAGE gel. Replicate Western blots were developed with either GlbN antiserum A or PetH (FNR)- or NifH-specific antibodies at primary dilutions of $1: 2,500,1: 800$, and 1:800, respectively. The pattern of bands shown is representative of that observed in three separate trials, with cells grown under these conditions. Molecular mass markers in kilodaltons $(18,27,32,49,80$, and 108, in ascending order) are indicated to the left of each panel. Arrows indicate the major bands detected with the respective antisera.

strain 7942, and Synechocystis sp. strain BO 8402 (data not shown; Table 1). In contrast, colonies of a strain of the nonheterocyst-forming filamentous marine bloom former $T$. thiebautii that were collected in situ and which were actively fixing nitrogen did contain the 18-kDa protein (Fig. 2D). Like GlbN, the $18-\mathrm{kDa}$ protein from $T$. thiebautii had a mobility in SDSPAGE gels which was unaffected by any lipid-soluble components present in the cell extracts (Fig. 2D).

$g l b N$ is not present in the nifU-nifH intergenic region of the independent isolates, i.e., Anabaena sp. strain PCC 7120, Anabaena sp. strain L31, Anabaena azollae 1a, and Plectonema boryanum $(12,18,24,37,38)$. However, in view of the finding

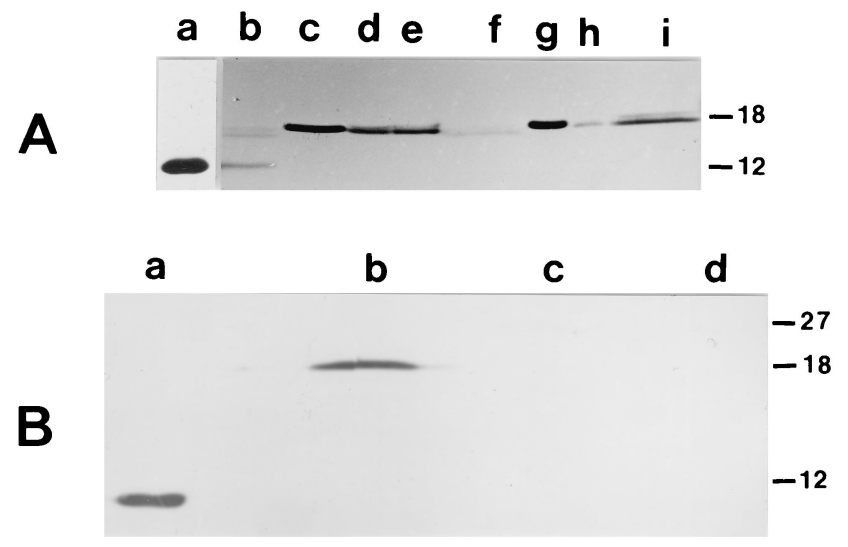

a b $\quad$ c $\quad d \quad$ e $f \quad g \quad h$

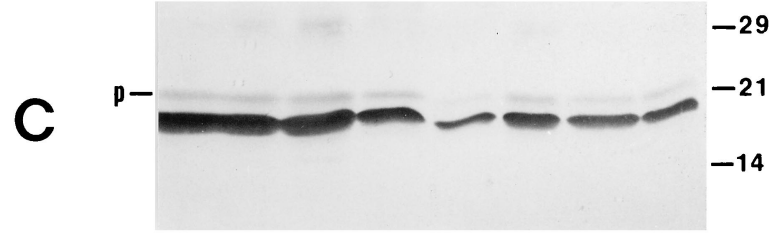

a

b

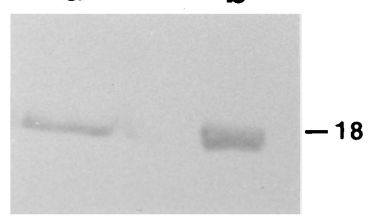

FIG. 2. Anabaena and Nostoc spp. contain a polypeptide that cross-reacts with GlbN-specific antibodies. (A) Protein extracts were prepared and resolved as described in the legend to Fig. 1. Western blots were developed with GlbN antiserum $\mathrm{A}$ at a primary dilution of 1:2,500. Western blots of total protein extracts from $N$. commune UTEX 584 (lanes b and f), A. variabilis ATCC 29413 (lanes c and g), Anabaena sp. strain PCC 7120 (lanes d and h), and Anabaena sp. strain PCC 7118 (lanes e and i) are shown. Strains were grown in BG-11 $\mathrm{O}$ under oxic gas conditions for approximately $168 \mathrm{~h}$ until they achieved logarithmic growth. Some aliquots of the cell suspensions were subjected to microoxic stepdown and incubated under microoxic conditions for $96 \mathrm{~h}$ (lanes b, c, d, and e); other aliquots of the cell suspensions were maintained under oxic conditions for $96 \mathrm{~h}$ (lanes f, g, h, and i). Lane a, $20 \mathrm{ng}$ of purified recombinant GlbN. (B) Western blot of total protein extracts from $N$. commune DRH1 (lane b), Nostoc sp. strain ATCC 27896 (lane c) and Nostoc sp. strain ATCC 29133 (lane d). The conditions of growth and induction of GlbN synthesis were as in panel A. Lane a, $20 \mathrm{ng}$ of purified recombinant GlbN. (C) Western blot of total protein extracts from A. variabilis ATCC 29413 (lanes a, b, c, and d) and Anabaena sp. strain PCC 7119 (lanes e, f, g, and h). In this experiment, cells were grown in fermentors under continuous light with Allen and Arnon media in the presence (lanes a and $\mathrm{b}$ and $\mathrm{e}$ and $\mathrm{f}$ ) or absence (lanes $\mathrm{c}$ and $\mathrm{d}$ and $\mathrm{g}$ and $\mathrm{h}$ ) of ammonia. Cells were washed and resuspended in fresh media, and aliquots of the cell suspension were transferred to $20-\mathrm{ml}$ capacity glass bottles and incubated either under anoxic conditions for $16 \mathrm{~h}$ (lanes a and $\mathrm{f}$ and $\mathrm{d}$ and $\mathrm{h}$ ) or under oxic conditions for $16 \mathrm{~h}$ (lanes $\mathrm{b}$ and $\mathrm{e}$ and $\mathrm{c}$ and $\mathrm{g}$ ). A purified preparation of heterocysts from $A$. variabilis ATCC 29413 gave cross-reactions similar to those shown in lane c (data not shown). No heterocysts were observed in cultures grown in the presence of ammonia. All cultures grown in the absence of ammonia reduced acetylene. $p$ (arrow), the position of pigmented phycobiliproteins (i.e., these are not signals due to immunoblotting). (D) Western blot of total protein extracts from colonies of $T$. thiebautii that actively fixed nitrogen in situ. Samples were prepared following treatment of the cells with guanidinium isothiocyanate (lane a) or by direct extraction of proteins in SDS-PAGE buffer (lane b).

of the $18-\mathrm{kDa}$ protein which cross-reacted with GlbN antiserum, we investigated whether $g l b N$ was present in these and a variety of other nitrogen-fixing cyanobacteria by Southern hybridization using a glbN gene fragment from Nostoc sp. 


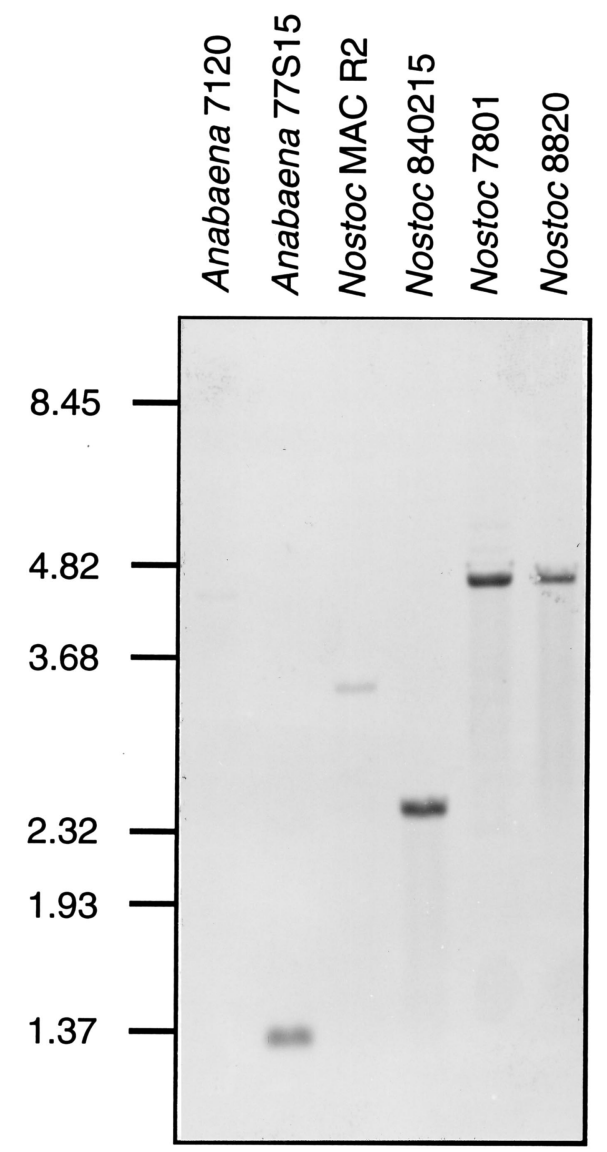

FIG. 3. Distribution of $g l b N$ in Anabaena and Nostoc strains. HindIII digests of genomic DNA from Anabaena sp. strain PCC 7120, Anabaena sp. strain PCC 77S15, Nostoc sp. strain MAC R2, Nostoc sp. strain 840215, Nostoc sp. strain UCD 7801, and Nostoc sp. strain 8820 were analyzed by Southern hybridization with a digoxigenin-labelled 270-bp $A l u \mathrm{I}$-glbN fragment from Nostoc sp. strain 8820 as a probe. Bacteriophage lambda BstEII fragments were used as size markers. Bound probe was detected with an alkaline phosphatase-conjugated anti-digoxigenin antibody and then by colorimetric detection.

strain 8820 as a probe. A single strong signal was observed with genomic digests of Nostoc sp. strain 840215, Nostoc sp. strain UCD 7801, and Nostoc sp. strain 8820 (Fig. 3) and with Nostoc sp. strain ATCC 27897 (data not shown). The single band observed suggested that $g l b N$ was present in a single copy in these three strains, as it is in N. commune UTEX 584. Weakly hybridizing bands were detected in genomic digests of six strains of cyanobacteria of section IV (Nostoc sp. strain MAC R2, Anabaena sp. strain PCC 77S15, Cylindrospermum sp. strain PCC 7604, Scytonema sp. strain PCC 7110, Tolypothrix sp. strain SAUG 1410-1, and Nodularia sp. strain PCC 73104 [Table 1; Fig. 3]). Preliminary nucleotide sequence data indicate that no glbN gene is present between nifU and nifH in Anabaena sp. strain PCC 77S15 (36). No significant hybridization signals were detected either in Anabaena sp. strain 7120 (with separate isolates of this strain and when either radioactively or nonradioactively labelled probes were used), Calothrix sp. strain PCC 7102, or any strains from sections III or $\mathrm{V}$ (Table 1).

The glbN region in Nostoc sp. strain 8820. A 4.5-kb HindIII fragment containing the nifH gene was isolated from a sizedirected library of Nostoc sp. strain 8820 HindIII fragments cloned in pUC18. The nucleotide sequence of a 1,229-bp region of this fragment was determined and compared with the equivalent region in $N$. commune UTEX 584. Nostoc sp. strain 8820 contains $g l b N$ positioned between nif $U$ and nifH as in $N$. commune UTEX 584, and the coding regions of these genes are very similar in both strains: nif $U$, glbN, and nifH are 98.7, 95.5, and $98.2 \%$ identical, and NifU, GlbN, and NifH are 98.7, 95.8, and $97.3 \%$ identical, respectively.

The $g l b N$-nifH and nifU-glbN intergenic regions of $N$. commune UTEX 584 contain a number of structural elements (2). The glbN-nifH regions of Nostoc sp. strain 8820 and N. commune UTEX 584 are almost identical in length (1-bp difference), with just 11 differences in $350 \mathrm{bp}$-an overall identity of $97 \%$. All of the structural elements noted in the glbN-nifH region of $N$. commune UTEX 584 are present in the equivalent region of Nostoc sp. strain 8820 . The following additional features and differences are annotated in the database entry: (i) a stem-loop structure ( 8 paired bases $)(-11.9 \mathrm{kcal}[1 \mathrm{cal}=4.184$ $\mathrm{J}] \mathrm{mol}^{-1}$ ) which contains the upstream activating sequence noted by Angeloni and Potts (2), (ii) a secondary structure (17 paired bases $\left.\left[-18.6 \mathrm{kcal} \mathrm{mol}^{-1}\right]\right)$ formed by five copies of the short tandem repeat sequences (STRR) ACAAAG $(\mathrm{A} / \mathrm{G})$ (three copies are found in N. commune UTEX 584), and (iii) the highly iterated palindromic repeat (HIP1) sequence GCG ATCGC that forms part of a third possible secondary structure (24 paired bases $\left[-23.4 \mathrm{kcal} \mathrm{mol}^{-1}\right]$ ).

The nifU-glbN intergenic regions of the two strains differ both in their lengths and in their nucleotide sequences. The region is $226 \mathrm{bp}$ in length in Nostoc sp. strain 8820 and $257 \mathrm{bp}$ in length in $N$. commune UTEX 584. The overall sequence identity is $74.2 \%$ because of $190 \mathrm{bp}$ that are identical between the two strains. Each nifU-glbN region has three distinct domains: (i) a conserved domain immediately following nifU that is $115 \mathrm{bp}$ in length with $91.3 \%$ identity between the two strains, (ii) a conserved domain prior to $g l b N$ that is $86 \mathrm{bp}$ in length with $83.7 \%$ identity between the two strains, and (iii) a central variable domain in which the major differences between the two strains occur.

The central domain is 25 bp in length in Nostoc sp. strain 8820 and 59 bp in length in N. commune UTEX 584 (positions 116 to 140 of Nostoc sp. strain 8820 and positions 115 to 173 of $N$. commune UTEX 584 [Fig. 4]). In $N$. commune UTEX 584, the domain includes two stretches of 14 and 20 nucleotides (nt) which are absent from Nostoc sp. strain 8820 . Furthermore, in $N$. commune UTEX 584, the variable domain contains four copies of the STRR sequence AATTACG; no copies are found in Nostoc sp. strain 8820. Each single strand of the entire nif $U$-glbN intergenic region of the two strains is capable of forming an extensive secondary structure (Fig. 4). In Nostoc sp. strain 8820,132 of 226 bases (58\% of the total) are paired, with a free energy of $-39.0 \mathrm{kcal} \mathrm{mol}^{-1}$; in N. commune UTEX 584, 140 of 257 bases $(54.5 \%)$ are paired, with a free energy of

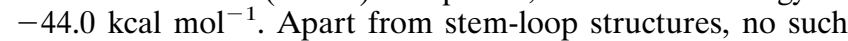
extensive secondary structure was detected in the glbN-nifH intergenic regions of Nostoc sp. strain 8820 or N. commune UTEX 584 or in the nifU-nifH intergenic region of Anabaena sp. strain PCC 7120.

Binding of NtcA to the $5^{\prime}$ region of $\boldsymbol{g l b N}$. The nucleotide sequence approximately $100 \mathrm{nt}$ upstream of the $g l b N$ translation initiation codon in N. commune UTEX 584 showed similarity with the sequence of the NtcA-binding site in the putative $\operatorname{gln} A$ promoter of Synechococcus sp. strain $7942(8,31)$ (Fig. 5A). The similarity included the presence of 5'TAGG3' at a position 22 bases downstream of the $5^{\prime} \mathrm{TAC3}^{\prime}$ element in the binding site but with the 5'GTA3'-5'TAC3' elements of the binding-site motif separated by 7 (not 8) bp (Fig. 5A). Further similarities included a complete correspondence between the $N$. commune UTEX 584 half-site sequence 5'ATT 

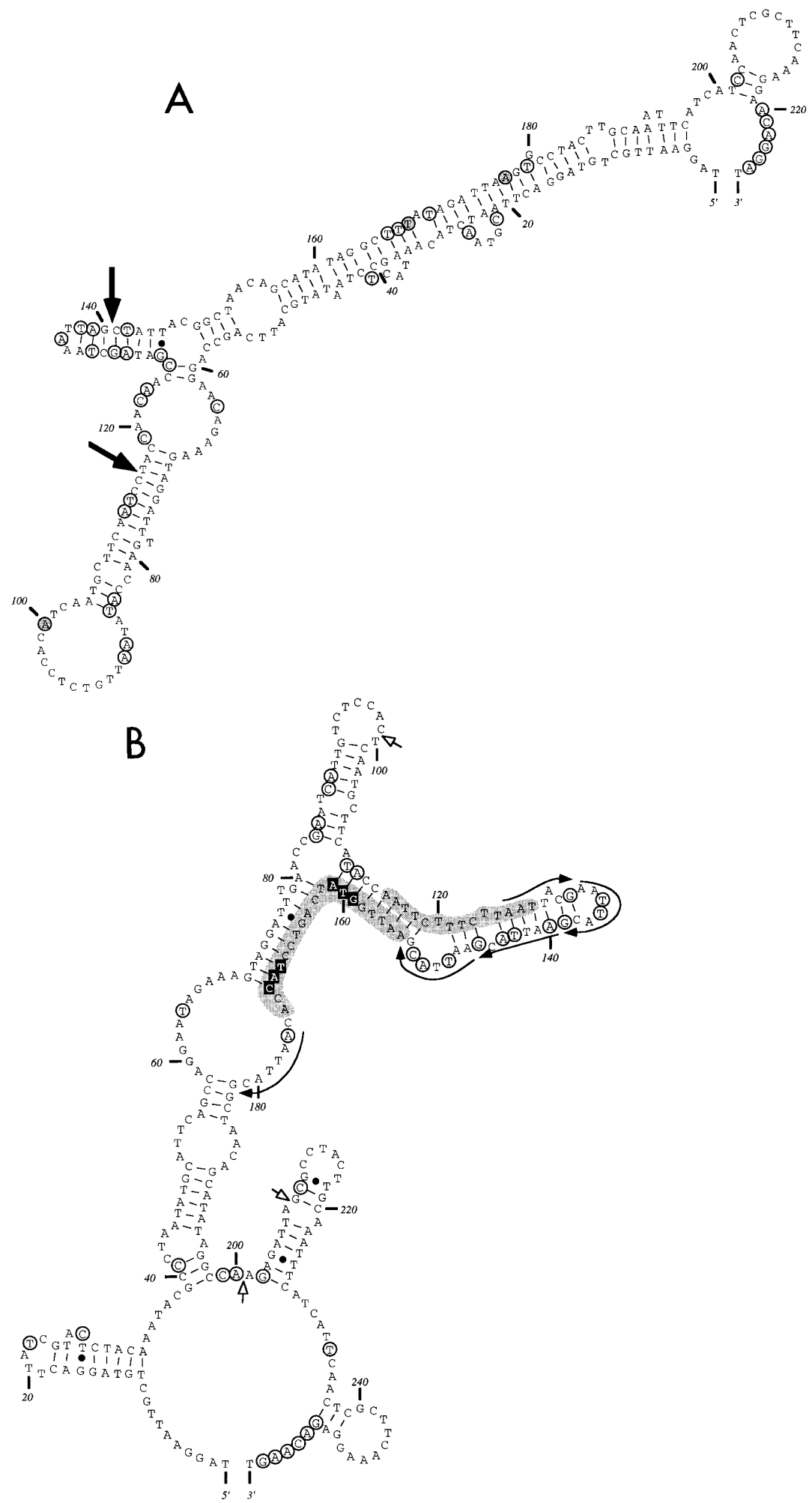

FIG. 4. The nifU-glbN intergenic regions of Nostoc sp. strain 8820 and $N$. commune UTEX 584 have extensive secondary structures. The nucleotide sequence of the $n i f U$-glbN intergenic region of Nostoc sp. strain 8820 (A) and N. commune UTEX 584 (B) were folded by using the program Mulfold, displayed with the program loopDloop, and annotated by hand. Circled positions indicate differences in the two sequences. Circled and shaded bases in Nostoc sp. strain 8820 are not found in $N$. commune UTEX 584, but their positions are indicated by short open arrows for the latter. Large solid arrows in panel A indicate the sites of the large insertions in the $N$. commune UTEX 584 sequence which are indicated by shaded regions in panel B. The STRR sequence, AATTACG, is indicated by arrows. The NtcA recognition sequence is indicated by reverse type. Numbering starts with the first base of the intergenic region. 


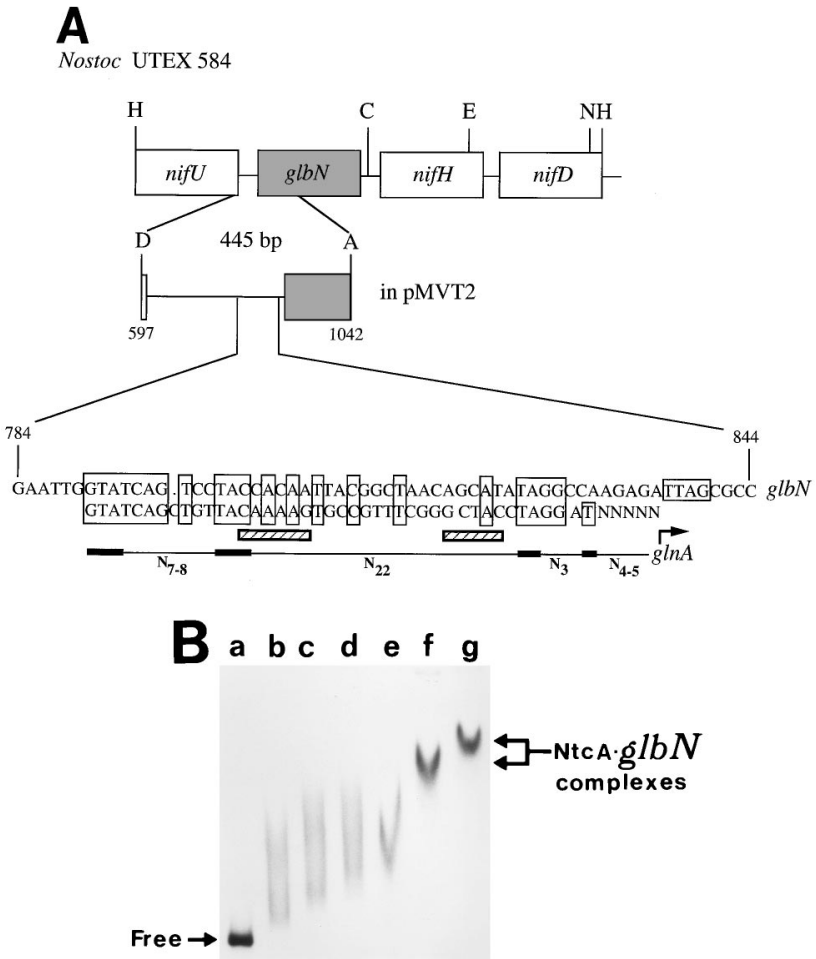

FIG. 5. The nif $U$-glbN intergenic region of $N$. commune UTEX 584 binds NtcA. (A) Restriction map of the nifU-glbN region of $N$. commune UTEX 584 showing the location of an NtcA-binding site upstream of $g l b N$. Sites for restriction enzymes HindIII (H), Cla I (C), EcoRI (E), Nhe I (N), AluI (A), and DpnI (D) are indicated. The nucleotide sequence of the NtcA-binding site of $N$. commune UTEX 584 (upper sequence) is compared with that in the $\ln A$ region of Synechococcus sp. strain PCC 7942 (lower sequence). Identities between the two sequences are boxed. Conserved NtcA-binding site elements (31) are indicated by black lines together with the spacing of the nucleotides. The putative glnA promoter (8) in Synechococcus sp. strain PCC 7942 is indicated by hatched underlining; the transcription start point of $g \ln A$ is indicated by an arrow. The rightmost TTAG box in the $g l b N$ sequence (positions 837 to 840 ) corresponds to a TTAG sequence very close to the transcription start point of $g \ln A$ from Anabaena sp. strain PCC 7120. Base 844 lies 45 bases upstream from the A of the ATG translation initiation codon of $N$. commune UTEX $584 \mathrm{glbN}$. (B) Synechococcus sp. strain 7942 NtcA binds to the 445-bp intergenic DraI-AluI fragment. Signals in the autoradiogram derive from the ${ }^{32} \mathrm{P}$-labelled 445 -bp fragment from pMVT2 (see panel A). Each lane contains approximately 20,000 cpm of target DNA (lane a [DNA only]), together with either 1 (lane b), 6 (lane c), and 12 (lane d) $\mu \mathrm{g}$ of cell lysate from DH5 (pTrc99A) or 1.5 (lane e), 6 (lane f), and 12 (lane g) $\mu \mathrm{g}$ of cell lysate from DH5 $\alpha(\mathrm{pCS} 126)$

GGTA3' and the NtcA half-site proximal to the coding region of nir (5'ATTGGTA3') in Synechococcus sp. strain 7942 (31; Fig. 5A). No such sequence similarity could be detected in Nostoc sp. strain 8820.

Mobility shift experiments were carried out to determine whether NtcA could bind to the putative NtcA binding site. A single, well-resolved band, with a marked retardation in mobility, was resolved in reactions that contained between 6 to 12 $\mu \mathrm{g}$ of protein extract from E. coli BL21 DE3(pCS126) which were induced for synthesis of NtcA and a purified ${ }^{32} \mathrm{P}$-labelled 445-bp DNA restriction fragment from the upstream region of glbN from $N$. commune UTEX 584 (Fig. 5A and B). This retardation was inhibited in reactions that were supplemented with between 100 and $300 \mathrm{ng}$ of competitor DNA. With $300 \mathrm{ng}$ of competitor DNA, the retardation of mobility and appearance of the signal were comparable to those shown in lane e of Fig. 5B. Footprint analyses confirmed that partially purified NtcA bound to the target DNA indicated in Fig. 5A (55).
Nonspecific retardation of migration of the 445-bp fragment, visualized as a smear on autoradiograms, occurred with reactions the mixtures for which contained protein extracts from E. coli BL21 DE3(pTrc99A). As judged from the degree of smearing that was examined in multiple trials, this nonspecific retardation was saturated in reaction mixtures that contained approximately $0.5 \mathrm{ng}$ of the target DNA fragment and $12 \mu \mathrm{g}$ of protein extract.

Cellular and subcellular location of GlbN in $N$. commune UTEX 584. The intracellular location of cyanoglobin in $N$. commune UTEX 584 cells was examined by electron microscopy by immunogold labelling with three different GlbN antisera. Thin sections of cells that were incubated for $12 \mathrm{~h}$ following microoxic stepdown were labelled heavily when antiserum A was used (Fig. 6A). The deposition of particles was associated only with cells, and no (or only a very rare) labelling of the extracellular sheath was detected (Fig. 6A). Labelling was detected in heterocysts and vegetative cells in approximately equivalent amounts. The labelling pattern included a random distribution throughout the cytoplasm as well as a conspicuous deposition around the periphery of the cells (Fig. 6A). The latter represented approximately 66\% of the total deposition in each cell. Sections of the same cells were labelled with fewer gold particles when GlbN antiserum B was used at the same dilution as antiserum A. The deposition of gold particles at the periphery of the cells was conspicuous and accounted for approximately $84 \%$ of the gold particles present (Fig. 6B). The amount of labelling was reduced still further when GlbN antiserum $\mathrm{C}$ was used at the same dilution (data not shown). In this case, the deposition of gold particles at the periphery of the cells accounted for approximately $90 \%$ of the total number of gold particles present. The depletion in titer of $\mathrm{GlbN}$-specific antibodies in antiserum $\mathrm{C}$ was expected in view of the presence of the $18-\mathrm{kDa}$ protein in Anabaena sp. strain PCC 7120 cell extracts that were used to cross-adsorb the serum (Materials and Methods). The use of serum that was preadsorbed with purified recombinant GlbN left sections that were completely devoid of gold particles-a result which was consistent with the lack of cross-reactivity when preimmune serum was used (data not shown).

The degree of labelling of cells that were grown under oxic conditions for $252 \mathrm{~h}$ was only slight when antiserum $\mathrm{C}$ was used (Fig. 7A) and was more or less equivalent to that seen for cells which had been incubated for $12 \mathrm{~h}$ following microoxic stepdown. In comparison, the use of antiserum $\mathrm{C}$ achieved an increase of greater than 1 order of magnitude in the gold labelling of cells grown under microoxic conditions for $84 \mathrm{~h}$ (Fig. 7B). Greater than $80 \%$ of the gold particles were located at and followed the contours of the cell membrane. The numbers of gold particles in these cells were even greater than those deposited in cells grown for $12 \mathrm{~h}$ under microoxic growth when they were labelled with antiserum A (i.e., compare Fig. $6 \mathrm{~A}$ and $7 \mathrm{~B}$ ). These data are consistent with those from Western blotting that indicated GlbN was not detectable in aerobically grown cells while there was a marked induction of GlbN synthesis following microoxic stepdown and incubation (Fig. $1)$.

N. commune UTEX 584 cells were induced for GlbN synthesis, and the soluble, cytoplasmic membrane, cell wall, and outer membrane fractions were obtained (41). GlbN was identified exclusively in the soluble protein fraction.

\section{DISCUSSION}

Cyanoglobin is restricted to Nostoc spp. Fourteen strains that represented three genera of filamentous non-heterocyst- 

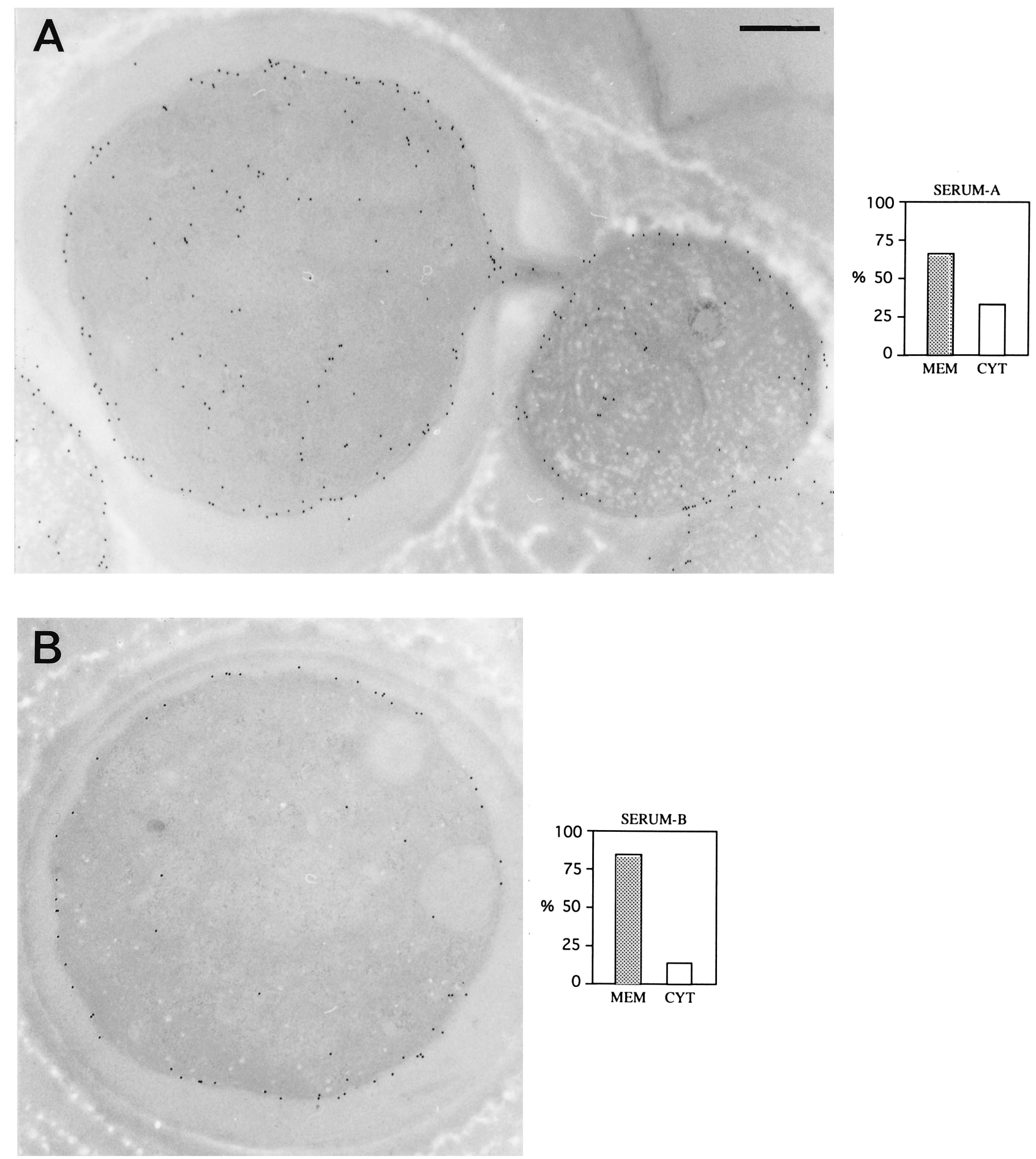

FIG. 6. GlbN is a peripheral membrane protein. Cells of $N$. commune UTEX 584 were grown in fermentors in BG- $11_{\mathrm{O}}$ under a $12 \mathrm{~h}: 12 \mathrm{~h}$ light-dark cycle for $168 \mathrm{~h}$ under oxic conditions. Following microoxic stepdown, they were incubated for $12 \mathrm{~h}$ to induce $\mathrm{GlbN}$ synthesis. Ultrathin sections were prepared for transmission electron microscopy and were immunogold labelled with either GlbN antiserum A or antiserum B at a 1:500 dilution. The patterns shown are representative of those observed with multiple sections seen in multiple fields of view. (A) Immunogold labelling of a representative heterocyst (left) and vegetative cell (right) with antiserum A. (B) Immunogold labelling of a representative heterocyst with antiserum B. In each case, the total numbers of gold particles in three representative cells were counted. Histograms indicate the mean numbers of gold particles at the cell membrane (MEM) versus those within the cell (CYT), expressed as a percentage of the total. Scale bar, approximately $2 \mu \mathrm{m}$. 

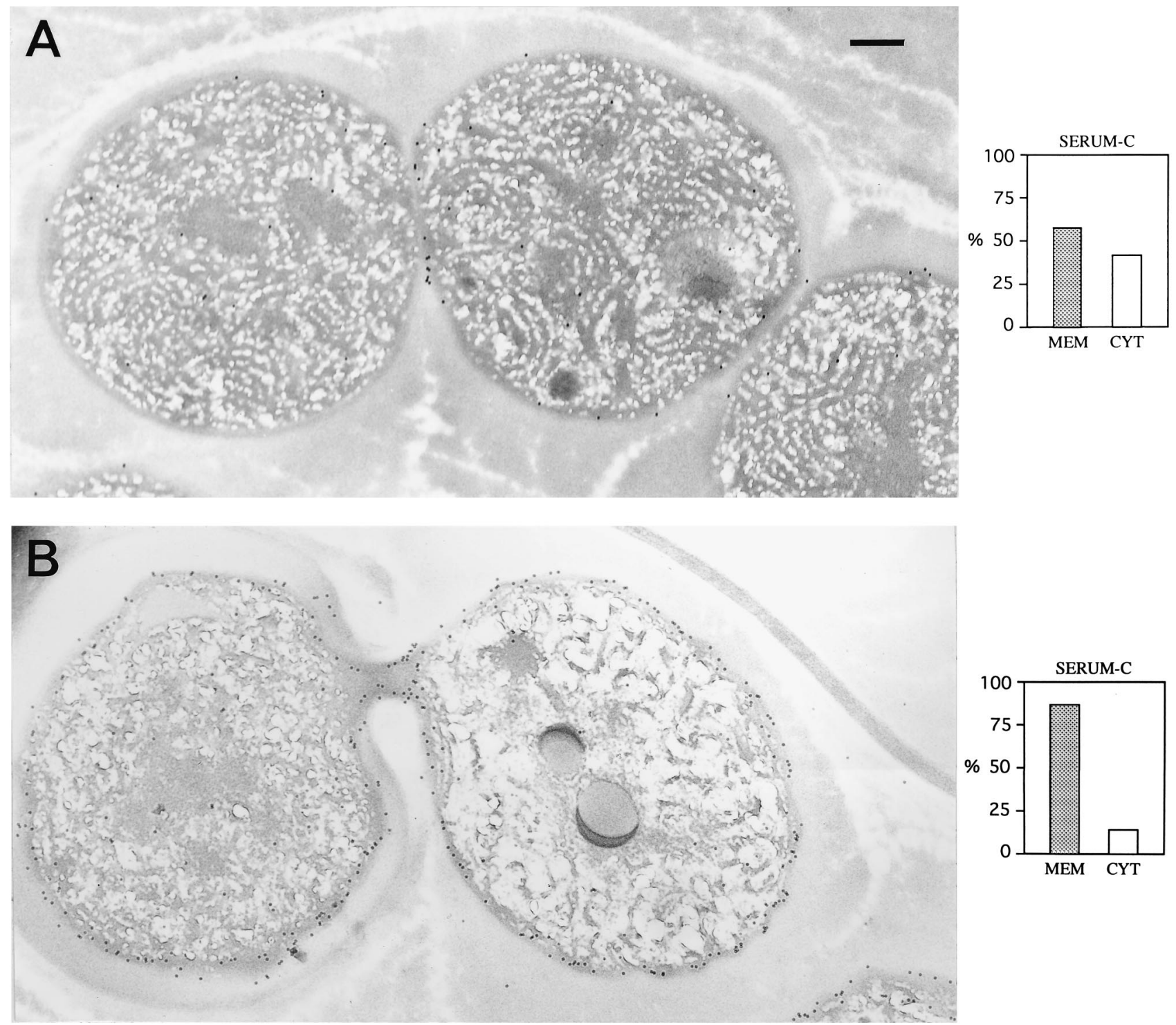

FIG. 7. GlbN synthesis is induced both in heterocysts and in vegetative cells specifically in response to microaerobic conditions. Cells of $N$. commune UTEX 584 were grown as described in the legend to Fig. 6 for either $252 \mathrm{~h}$ under oxic conditions (A) or for $168 \mathrm{~h}$ under oxic conditions and then for $84 \mathrm{~h}$ under microoxic conditions (B). Ultrathin sections were immunogold labelled with GlbN antiserum C. Scale bar, approximately $1 \mu \mathrm{m}$. See the legend to Fig. 6 for description of the histograms.

forming cyanobacteria (section III) and five genera of filamentous heterocyst-forming cyanobacteria (sections IV and V), including Anabaena sp. strain PCC 7120, provided no hybridization with a Nostoc sp. strain $8820 \mathrm{glbN}$ probe. Western blotting with GlbN antibodies failed to identify any cross-reactive protein with a size equivalent to that of GlbN of $N$. commune UTEX 584 in three unicellular-coccoid cyanobacteria and two non-heterocyst-forming filamentous cyanobacteria (sections I, II, and III). If these data reflect the fact that GlbN homologs are absent from these strains, then cyanoglobin is restricted to a subset of Nostoc sp. strains in which $g l b N$ was identified, including N. commune UTEX 584, Nostoc sp. strain 8820, Nostoc sp. strain 840215, Nostoc sp. strain UCD 7801, and Nostoc sp. strain ATCC 27897. Such a restricted distribution of $g l b N$ suggests that the gene may provide a useful genotypic marker for taxonomic purposes.

Anabaena sp. strain PCC 7120, as well as 8 other Anabaena,
Nostoc, and Trichodesmium strains, contained an 18-kDa polypeptide that cross-reacted with GlbN antibodies. However, the $18-\mathrm{kDa}$ protein is unlikely to be cyanoglobin. First, it is significantly different in size from cyanoglobin. Second, it is synthesized constitutively, unlike cyanoglobin, whose synthesis is inducible. Third, Anabaena sp. strain PCC 7120 DNA provided no significant signals with a $g l b N$ probe. Nevertheless, the cross-reaction between the 18-kDa protein and GlbN antibodies did appear to be highly specific given the purity of the antiserum, the dilution of the serum $(1: 10,000)$ at which strong reactions were obtained in Western analyses, the capacity of Anabaena sp. strain PCC 7120 extracts to substantially deplete the titer of the GlbN antiserum, and the lack of cross-reactivity between the GlbN serum and myoglobin or leghemoglobin (54).

Expression of $\boldsymbol{g l b N}$. NtcA was originally identified in Synechococcus sp. strain 7942 as a positive regulator protein that 
binds to the promoters of nitrogen-regulated genes such as the one that encodes nitrate reductase. Sequences hybridizing to $n t c A$ were detected in a wide range of cyanobacteria. A homolog of NtcA, which was characterized in Anabaena sp. strain PCC 7120, was found to be synonymous with BifA (VF1), which binds to three adjacent sites in the upstream region of the xis $A$ gene, which encodes a site-specific recombinase involved in the excision of an 11-kb DNA fragment from within nifD $(6,57)$. NtcA is also required for heterocyst differentiation in Anabaena sp. strain PCC 7120 (57). This protein clearly has multiple regulatory roles.

The similarity between the regions both upstream and downstream of $g l b N$ in N. commune UTEX 584 and Nostoc sp. strain 8820 is high, but it is surprising that Nostoc sp. strain 8820 apparently lacks the NtcA-binding site identified in the nifU$g l b N$ intergenic region of $N$. commune UTEX 584. Although the mode of regulation of $g l b N$ expression by NtcA is not known at this time, we would have expected it to be consistent between strains which contain $g l b N$; this may not be the case. It is not known whether the other strains in which $g l b N$ has been identified have NtcA-binding sites upstream of $g l b N$.

Hemoproteins and nitrogen fixation. Cyanoglobin is a hemoprotein that binds oxygen reversibly and with high affinity (54). Hemoproteins have at least three known functions related to nitrogen fixation. First, the terminal ( $d$ type) cytochrome oxidases in branched electron transport systems remove $\mathrm{O}_{2}$, thereby protecting nitrogenase (20). Second, leghemoglobins in plant cells facilitate $\mathrm{O}_{2}$ flux to vigorously respiring Rhizobium bacteroides at a stabilized low $\mathrm{O}_{2}$ tension (3). Third, hemoproteins, such as FixL (an oxygen-sensor and kinase) in $R$. meliloti, may have regulatory functions in nitrogen fixation (15). Specifically, for cyanobacteria, it has been suggested that hemoproteins in the cell wall and in the honeycomb membrane system of the heterocyst play a part in the binding of oxygen or protection of the nitrogenase complex (39). The subcellular location of these proteins in heterocysts was determined by their ability to oxidize 3,3'-diaminobenzidine in the dark. Cyanoglobin does oxidize 3,3'-diaminobenzidine (55), and it is also a hemoprotein which accumulates in the cell wall of heterocysts. However, the conditions under which cyanoglobin is synthesized, as well as the apparent lack of sequences which are homologous to $g l b N$ in a number of Nostoc and Anabaena spp., seem to exclude a general function for GlbN in the 3,3'-diaminobenzidine staining of the honeycomb region of heterocysts $(10,33,39)$.

The recent finding of a second Nif system in $A$. variabilis ATCC 29413, which is induced under anoxic conditions and which is expressed both in heterocysts and in vegetative cells $(50,53)$, emphasizes how the role of oxygen in the regulation of nitrogen fixation is a complex one. It is unlikely that cyanoglobin plays a role in this system. Southern and Western analyses failed to identify any $g l b N$ or GlbN homologs in $A$. variabilis ATCC 29413. In addition, no glbN sequence was found in the nif1, nif2, $f d x H 1$, or $f d x H 2$ gene clusters of this strain (32, $50,53)$.

A hemoprotein that shares both some sequence similarity and possible functional similarity with cyanoglobin is the cytochrome oxidase (nitrite reductase) of Pseudomonas perfectomarina (data not shown). This is a periplasmic protein whose synthesis is induced by anoxic conditions and nitrite and is repressed by nitrate and inhibited by oxygen (27). Similarly, cyanoglobin is, as we have shown here, a peripheral membrane protein; its synthesis is induced by anoxic conditions and is repressed by nitrate and oxygen.

Function of cyanoglobin. Collectively, the data presented here suggest that the physiological function of cyanoglobin is connected with nitrogen fixation. First, GlbN was synthesized only in cells grown in the absence of combined nitrogen. Second, conditions which induced the greatest levels of GlbN synthesis provided cells with the greatest capacity for acetylene reduction. Third, there was a marked correlation between the accumulation of GlbN, NifH, and PetH. Fourth, in the two Nostoc strains for which sequence data are available, a single copy of $g l b N$ was present between two nif operons: immediately downstream of nifU and immediately upstream of nifH. Fifth, NtcA, a transcription factor which binds near the promoters of nitrogen-regulated genes and which is required for heterocyst differentiation (57), binds immediately upstream of $g l b N$ in $N$. commune UTEX 584.

Given the available data, a plausible role for cyanoglobin is that it scavenges oxygen and provides that oxygen to, and as a peripheral component of, a cytochrome oxidase complex when ATP generation and, thus, nitrogen fixation are limited. Experiments to confirm or discount this hypothesis are in progress.

\section{ACKNOWLEDGMENTS}

We are grateful to Antonio Herrero for providing plasmids, Paul Ludden and Siegfried Scherer for antibodies, Herbert Böhme for clarifying the origin of Nostoc sp. strain 8820, Bernhardt Schrautemeier for an unpublished manuscript, and Karin Jäger for unpublished data.

This study was supported by the Sonderforschungsbereich 248 of the University of Konstanz (P.B. and S.B.) and by grants from the National Science Foundation of the United States (DCB-9103232, IBN-9513157, and INT-9022737 to M.P. and OCE-9115706 to H.P.), the Natural Sciences and Engineering Research Council of Canada (OGP-0041828 to M.E.M.), and the NATO Collaborative Research Grants program (910120 to M.P. and S. Scherer) and by a John Lee Pratt undergraduate fellowship in animal nutrition (D.B.). Stephen Murphy provided help with DNA sequencing.

\section{ADDENDUM IN PROOF}

ORF slr2097 in the genome sequence of Synechocystis sp. strain PCC 6803 (Cyanobase; http://www.kazusa.or.jp/cyano/) is annotated as $g l b N$ based on sequence similarity between its putative product and protozoan myoglobins (49\% identity). ORF slr2097 is not equivalent to $N$. commune $584 \mathrm{glbN}$ because the two DNA sequences share only $51 \%$ identity and the slr2097 and $N$. commune 584 glbN products share only $38 \%$ identity. Any reference to "glbN" in Synechocystis sp. strain PCC 6803 will clearly cause confusion in view of the potential use of $N$. commune $584 \mathrm{glbN}$ as a taxonomic marker. We recommend that ORF slr2097 be renamed. If the product of ORF slr2097 is a hemoprotein then it may represent a new example of the growing class of bacterial globins.

\section{REFERENCES}

1. Allen, M. B., and D. I. Arnon. 1955. Studies on nitrogen-fixing blue-green algae. I. Growth and nitrogen fixation by Anabaena cylindrica Lemm. Plant Physiol. 30:366-372.

2. Angeloni, S. V., and M. Potts. 1994. Analysis of the sequences within and flanking the cyanoglobin-encoding gene, $g l b N$, of the cyanobacterium Nostoc commune UTEX 584. Gene 146:133-134.

3. Appleby, C. A. 1984. Leghaemoglobin and Rhizobium respiration. Annu. Rev. Plant Physiol. 35:443-478.

4. Ausubel, F. M., R. Brent, R. E. Kingston, D. D. Moore, J. G. Seidman, J. A Smith, and K. Struhl. 1987. Current protocols in molecular biology. Greene Publishing Associates and Wiley-Interscience, New York.

5. Buikema, W. J., and R. Haselkorn. 1993. Molecular genetics of cyanobacterial development. Annu. Rev. Plant Physiol. Plant Mol. Biol. 44:33-52.

6. Chastain, C. J., J. S. Brusca, T. S. Subramanian, T.-F. Wei, and J. W. Golden. A sequence-specific DNA-binding factor (VF1) from Anabaena sp. strain PCC 7120 vegetative cells binds to three adjacent sites in the xis $A$ upstream region. J. Bacteriol. 172:5044-5051.

7. Chu, S. P. 1942. The influence of the mineral composition of the medium on the growth of planktonic algae. I. Methods and culture media. J. Ecol. 30:284-325. 
8. Cohen-Kupiec, R., A. Zilberstein, and M. Gurevitz. 1995. Characterization of cis elements that regulate the expression of $g \ln A$ in Synechococcus sp. strain PCC 7942. J. Bacteriol. 177:2222-2226.

9. Defrancesco, N., and M. Potts. 1988. Cloning of nifHD from Nostoc commune UTEX 584 and of a flanking region homologous to part of the Azotobacter vinelandii nifU gene. J. Bacteriol. 170:3297-3300.

10. Ernst, A., T. Black, Y. Cai, J. M. Panoff, D. N. Tiwari, and C. P. Wolk. 1992. Synthesis of nitrogenase in mutants of the cyanobacterium Anabaena sp. strain PCC 7120 affected in heterocyst development or metabolism. J. Bacteriol. 174:6025-6032.

11. Fay, P. 1992. Oxygen relations of nitrogen fixation in cyanobacteria. Microbiol. Rev. 56:340-373.

12. Fujita, Y., Y. Takahashi, F. Shonai, Y. Ogura, and H. Matsubara. 1991. Cloning, nucleotide sequence and differential expression of the nifH and nifH-like $(f r x C)$ genes from the filamentous nitrogen-fixing cyanobacterium Plectonema boryanum. Plant Cell Physiol. 32:1093-1106.

13. Geitler, L. 1932. Krytogamen-Flora von Deutschland, Österreich und der Schweiz. Akademische Verlagsgesellschaft m.b.H., Leipzig, Germany.

14. Gilbert, D. G. 1990. LoopDLoop, a Macintosh program for visualising RNA secondary structure. Available via anonymous ftp to ftp.bio.indiana.edu.

15. Gilles-Gonzalez, M. A., G. S. Ditta, and D. R. Helinski. 1991. A haemoprotein with kinase activity encoded by the oxygen sensor of Rhizobium meliloti. Nature (London) 350:170-172.

16. Gruber, A., and B. Zingales. 1995. Alternative method to remove antibacterial antibodies from antisera used for screening of expression libraries. BioTechniques 19:29-30.

17. Häfele, U., S. Scherer, and P. Böger. 1988. Cytochrome $a a_{3}$ from heterocysts of the cyanobacterium Anabaena variabilis: isolation and spectral characterization. Biochem. Biophys. Acta 934:190-196.

18. Haselkorn, R. 1992. Developmentally regulated gene rearrangements in prokaryotes. Annu. Rev. Genet. 26:113-130.

19. Haselkorn, R., and W. J. Buikema. 1992. Nitrogen fixation in cyanobacteria p. 166-190. In G. Stacey, R. H. Burris, and H. J. Evans (ed.), Biological nitrogen fixation. Chapman and Hall, New York.

20. Hill, S. 1992. Physiology of nitrogen fixation in free-living heterotrophs, p. 87-134. In G. Stacey, R. H. Burris, and H. J. Evans (ed.), Biological nitrogen fixation. Chapman and Hall, New York.

21. Hill, D. R., S. Hladun, S. Scherer, and M. Potts. 1994. Water stress proteins of Nostoc commune (Cyanobacteria) are secreted with UV-A/B-absorbing pigments and associate with 1,4- $\beta$-D-xylanxylanohydrolase activity. J. Biol. Chem. 269:7726-7734

22. Hill, D. R., A. Peat, and M. Potts. 1994. Biochemistry and structure of the glycan secreted by desiccation-tolerant Nostoc commune (Cyanobacteria). Protoplasma 182:126-148.

23. Huynh, T. V., R. A. Young, and R. W. Davis. 1985. Constructing and screening cDNA libraries in $\lambda$ gt10 and $\lambda$ gt11, p. 49-78. In D. M. Glover (ed.), DNA cloning, vol. 1. IRL Press, Oxford.

24. Jackman, D. M., and M. E. Mulligan. 1995. Characterization of a nitrogenfixation (nif) gene cluster from Anabaena azollae 1a shows that closely related cyanobacteria have highly variable but structured intergenic regions. Microbiology 141:2235-2244.

25. Jaeger, J. A., D. H. Turner, and M. Zuker. 1989. Improved predictions of secondary structures for RNA. Proc. Natl Acad. Sci. USA 86:7706-7710.

26. Jaeger, J. A., D. H. Turner, and M. Zuker. 1989. Predicting optimal and suboptimal secondary structure for RNA. Methods Enzymol. 183:281-306.

26a.Jäger, K., and B. Holtmann. Personal communication.

27. Jüngst, X., A. Wakabayashi, H. Matsubara, and W. G. Zumft. 1991. The nirSTBM region coding for cytochrome $\mathrm{cd}_{1}$-dependent nitrite respiration of Pseudomonas stutzeri consists of a cluster of mono-, di- and tetraheme proteins. FEBS Lett. 279:205-209.

28. Kallio, P. T., D. J. Kim, P. S. Tsai, and J. E. Bailey. 1994. Intracellular expression of Vitreoscilla hemoglobin alters Escherichia coli energy metabolism under oxygen-limited conditions. Eur. J. Biochem. 219:201-208.

29. Kangatharalingham, N., J. C. Priscu, and H. Paerl. 1992. Heterocyst envelope thickness, heterocyst frequency and nitrogenase activity in Anabaena flos-aquae: influence of exogenous oxygen tension. J. Gen. Microbiol. 138: 2673-2678.

30. Laemmli, U. K. 1970. Cleavage of structural proteins during the assembly of the head of bacteriophage T4. Nature (London) 227:680-685.

31. Luque, I., E. Flores, and A. Herrero. 1994. Molecular mechanisms for the operation of nitrogen control in cyanobacteria. EMBO J. 13:2862-2869.

32. Lyons, E. M., and T. Thiel. 1995. Characterization of nifB, nifS, and nifU genes in the cyanobacterium Anabaena variabilis: NifB is required for the vanadium-dependent nitrogenase. J. Bacteriol. 177:1570-1575.

33. Maldener, I., G. Fiedler, A. Ernst, F. Fernandez-Pinas, and C. P. Wolk. 1994 Characterization of $\operatorname{dev} A$, a gene required for the maturation of proheterocysts in the cyanobacterium Anabaena sp. strain PCC 7120. J. Bacteriol. 176:7543-7549.
34. Matsudaira, P. 1987. Sequence from picomole quantities of proteins electroblotted onto polyvinylidene difluoride membranes. J. Biol. Chem. 262: 10035-10038.

35. Merril, C. R., M. C. Dunau, and D. Goldman. 1981. A rapid sensitive silver stain for polypeptides in polyacrylamide gels. Anal. Biochem. 110:201-207. 36. Mulligan, M. E. 1996. Unpublished data.

37. Mulligan, M. E., and R. Haselkorn. 1989. Nitrogen fixation (nif) genes of the cyanobacterium Anabaena species strain PCC 7120. The nifB-fdxN-nifS-nifU operon. J. Biol. Chem. 264:19200-19207.

38. Murphy, S. T., D. M. Jackman, and M. E. Mulligan. 1993. Cloning and nucleotide sequence of the gene for dinitrogenase reductase (nifH) from the heterocyst-forming cyanobacterium Anabaena sp. L31. Biochim. Biophys. Acta 11:337-340.

39. Murry, M. A., A. G. Olafsen, and J. R. Benemann. 1981. Oxidation of diaminobenzidine in the heterocysts of Anabaena cylindrica. Curr. Microbiol. 6:201-206.

40. Murry, M. A., and C. P. Wolk. 1989. Evidence that the barrier to the penetration of oxygen into heterocysts depends upon two layers of the cell envelope. Arch. Microbiol. 151:469-474.

41. Olie, J. J., and M. Potts. 1986. Purification and biochemical analysis of the cytoplasmic membrane from the desiccation-tolerant cyanobacterium Nostoc commune UTEX 584. Appl. Environ. Microbiol. 52:706-710.

42. Potts, M., S. V. Angeloni, R. E. Ebel, and D. Bassam. 1992. Myoglobin in a cyanobacterium. Science 256:1690-1692.

43. Potts, M., and M. A. Bowman. 1985. Sensitivity of Nostoc commune UTEX 584 to water stress. Arch. Microbiol. 141:51-56.

44. Prufert-Bebout, L., H. W. Paerl, and C. Lassen. 1993. Growth, nitrogen fixation, and spectral attenuation in cultivated Trichodesmium species. Appl. Environ. Microbiol. 59:1367-1375.

45. Rippka, R. 1988. Recognition and identification of cyanobacteria. Methods Enzymol. 167:28-67.

45a.Rippka, R. Personal communication.

46. Rippka, R., J. Deruelles, J. B. Waterbury, M. Herdman, and R. Y. Stanier. 1979. Generic assignments, strain histories and properties of pure cultures of cyanobacteria. J. Gen. Microbiol. 111:1-61.

47. Sambrook, J., E. F. Fritsch, and T. Maniatis. 1989. Molecular cloning: laboratory manual. Cold Spring Harbor Laboratory Press, Cold Spring Harbor, N.Y.

48. Scherer, S., W. Kerfin, and P. Böger. 1980. Increase of nitrogenase activity in the blue-green alga Nostoc muscorum (Cyanobacterium). J. Bacteriol. 144:1017-1023.

49. Scherer, S., and M. Potts. 1989. Novel water stress protein from a desiccation-tolerant cyanobacterium. Purification and partial characterization. J. Biol. Chem. 264:12546-12553.

50. Schrautemeier, B., U. Neveling, and S. Schmitz. 1995. Distinct and differently regulated Mo-dependent nitrogen-fixing systems evolved for heterocysts and vegetative cells of Anabaena variabilis ATCC 29413: characterization of the $f d x H 1 / 2$ gene regions as part of the nif1/2 gene clusters. Mol. Microbiol. 18:357-369.

51. Smith, R. L., C. VanBaalen, and F. R. Tabita. 1987. Alteration of the Fe protein of nitrogenase by oxygen in the cyanobacterium Anabaena sp. strain CA. J. Bacteriol. 169:2537-2542.

52. Stewart, W. D. P., G. P. Fitzgerald, and R. H. Burris. 1968. Acetylene reduction by nitrogen-fixing blue-green algae. Arch. Mikrobiol. 62:336-348.

53. Thiel, T., E. M. Lyons, J. C. Erkner, and A. Ernst. 1995. A second nitrogenase in vegetative cells of a heterocyst-forming cyanobacterium. Proc. Natl. Acad. Sci. USA 92:9358-9362.

54. Thorsteinsson, M. V., D. R. Bevan, R. E. Ebel, R. E. Weber, and M. Potts 1996. Spectroscopical and functional characterization of the hemoglobin of Nostoc commune UTEX 584 (Cyanobacteria). Biochim. Biophys. Acta 1292: 133-139.

55. Thorsteinsson, M. V., and M. Potts. 1996. Unpublished data

56. Vasudevan, S. G., W. L. F. Armarego, D. C. Shaw, P. E. Lilley, N. E. Dixon, and R. K. Poole. 1991. Isolation and nucleotide sequence of the hmp gene that encodes a haemoglobin-like protein in Escherichia coli K-12. Mol. Gen. Genet. 226:49-58

57. Wei, T.-F., T. S. Ramasubramanian, and J. W. Golden. 1994. Anabaena sp. strain PCC $7120 n t c A$ gene required for growth on nitrate and heterocys development. J. Bacteriol. 176:4473-4482.

58. Wolk, C. P. 1991. Genetic analysis of cyanobacterial development. Curr Opin. Genet. Dev. 1:336-341.

59. Wolk, C. P., A. Ernst, and J. Elhai. 1994. Heterocyst metabolism and development, p. 769-823. In D. A. Bryant (ed.), The molecular biology of cyanobacteria. Luwer Academic Publishers, Dordrecht, The Netherlands.

60. Xie, W.-Q., and M. Potts. 1991. Gene cluster rpoBC1C2 in cyanobacteria does not constitute an operon. Arch. Biochem. Biophys. 284:22-25.

61. Zuker, M. 1989. On finding all suboptimal foldings of an RNA molecule. Science 244:48-52. 